\title{
Revisão de Euprepina Hull (Diptera, Bombyliidae, Bombyliinae)
}

\author{
Carlos José Einicker Lamas ${ }^{1}$ \\ Márcia Souto Couri ${ }^{1,2}$
}

\begin{abstract}
Revision of Euprepina Hull (Diptera, Bombyliidae, Bombyliinae). Euprepina Hull, 1971 (Diptera, Bombyliidae, Bombyliinae) a neotropical genus with ten species is revised. Redescriptions of eight species were made: $E$. nuda Hull, 1971, E. amabilis (Wulp, 1881), E. beckeri Lamas \& Couri, 1998, E. bicincta (Wiedemann, 1830), E. caminaria (Wiedemann, 1830), E. knutsoni Hull, 1971, E. maracajula Hull, 1971 and E. truxalia Hull, 1971, with illustrations of the types, male terminalia and spermathecae. Two synonymies - E. bicincta (Wiedemann, 1830), syn.: E. bicincta Hull, 1971; and E. nuda Hull, 1971, syn.: E. shannoni Hull, 1971 - are proposed. A key to species are presented except to E. goyaz (Macquart, 1840) and E. aperta (Macquart, 1847), which were not included in this study, as no material was examined. KEY WORDS. Bombyliidae; Bombyliinae; Diptera; Euprepina; Taxonomy.
\end{abstract}

HUll (1971) descreveu o gênero Euprepina, designando como espécie tipo E. nuda. Descreveu ainda cinco espécies (E. shannoni, E. maracajula, E. bicincta, E. truxalia, E. knutsoni), baseado em material proveniente da América do Sul. Considerou o gênero relacionado à Sparnopolius Loew, 1855, assemelhando-o morfologicamente a este pela cobertura orogenal estendida, nua e polida. Por outro lado, os dois gêneros diferem na posição da veia transversal r-m, localizada no 1/3 posterior da célula discal em Euprepina, e antes da metade da célula discal em Sparnopolius; e pela presença de um tufo de longos pêlos em frente aos halteres em Euprepina. O autor sugeriu ainda, que Sparnopolius deveria incluir as espécies neárticas e Euprepina as neotropicais.

HULL (1973) redescreveu Euprepina, incluindo-o em uma chave para separação dos gêneros da subfamília Bombyliinae. Transferiu para Sparnopolius duas espécies descritas por WIEDEMANN (1830), Bombylius bicinctus e B. caminarius.

PAINTER \& PAINTER (1974) transferiram para Sparnopolius, Dischistus amabilis Wulp, 1881 e Bombylius goyaz Macquart, 1840, porém sem justificar as novas combinações. Redescreveram os tipos das espécies de Sparnopolius, hoje consideradas Euprepina - S. amabilis (Wulp, 1881), S. bicinctus (Wiedemann, 1830), S. caminarius (Wiedemann, 1830) e S. goyaz (Macquart, 1840).

1) Museu Nacional. Quinta da Boa Vista, São Cristóvão, 20940-040 Rio de Janeiro, Rio de Janeiro, Brasil.

2) Bolsista do CNPq.

Revta bras. Zool. 16 (2): 461 - 482, 1999 
PAINTER et al. (1978) transferiram para Euprepina - Sparnopolius amabilis (Wulp), S. bicinctus (Wiedemann), S. caminarius (Wiedemann) e S. goyaz (Macquart) -, passando o gênero então a compreender dez espécies neotropicais. Afirmaram ainda, que poderiam existir sinônimos nas espécies descritas por HuLL (1971), e que se E. bicincta Hull, 1971 for uma espécie válida, necessitaria de um novo nome pois este já está pré-ocupado por E. bicincta (Wiedemann, 1830).

EvenHuIs (1983) transferiu Sparnopolius apertus (Macquart, 1847) para Euprepina, incluindo-a desta forma na listagem de espécies, porém sem justificar a nova combinação.

LAMAS \& COURI (1998) acrescentaram uma espécie nova ao gênero $E$. beckeri, considerando-a morfologicamente similar a E. truxalia por serem as únicas espécies do gênero com labelo longo.

Uma revisão taxonômica de Euprepina era necessária, tendo em vista as várias questões existentes como: espécies com o mesmo nome, suspeitas de sinonímias levantadas (PAINTER et al. 1978), e ainda a necessidade de redescrever mais detalhadamente as espécies, e elucidar caracteres para utilização em análise cladística.

\section{MATERIAL E MÉTODOS}

O material estudado neste trabalho pertence às coleções das instituições abaixo relacionadas, em ordem alfabética (com o nome dos responsáveis pelos empréstimos entre parênteses): CNC - Canadian National Collection, Ontario, Canadá (Dr. J.M. Cumming); ITZA - Instituut voor Taxonomische Zoologie, Amsterdam, Holanda (Dr. B. Brugge); MNRJ - Museu Nacional do Rio de Janeiro, Rio de Janeiro, Brasil (Dra. Márcia Couri); MZUSP - Museu de Zoologia da Universidade de São Paulo, São Paulo, Brasil (Dr. José Henrique Guimarães); NMW -Naturhistorisches Museum, Viena, Áustria (Dr. Ruth Contreras-Lichtenberg); UQIC - University of Queensland Insect Collection, Queensland, Australia (Dr. David Yeates); NMNH - National Museum of Natural History, Smithsonian Institution, Washington D.C., Estados Unidos (Dr. Neal Evenhuis Bernice Pauahi Bishop Museum, Honolulu, Hawai).

Euprepina goyaz e E. aperta não estão incluídas nesta revisão, pois não foi possível examinar o material tipo destas espécies, e por não haver outros exemplares depositados em coleções. Não foram examinados também, exemplares fêmeas de E. maracajula, E. caminaria e E. amabilis, sendo que destas três espécies, somente a fêmea de $E$. caminaria é conhecida.

A terminologia utilizada foi a de MCALPINE (1981), exceto para "célula discal medial", onde preferiu-se seguir YEATES (1988) que usa simplesmente "célula discal". Como a terminologia utilizada para as estruturas da espermateca varia entre diferentes autores, apresentamos uma lista (Tab. I), na qual os termos empregados neste trabalho estão em itálico, seguidos dos outros termos para a mesma estrutura, utilizados pelos diferentes autores (assinalados por "="). Cada termo é seguido por sua abreviatura e uma referência bibliográfica, que inclui autor, ano, página e figuras. Foram utilizados os termos de MCALPINE (1981), acrescidos 
daqueles usados por YEATES (1994) e ARTIGAS (1971) que não foram referidos por MCALPINE (1981). Os termos "duto espermático apical"e "duto espermático basal" (Mühlenberg 1970 in YEATES 1994), são usuais para espermatecas como a dos Bombyliidae, que possuem uma bomba de esperma neste duto, dividindo-o em duas partes, mas apesar disto, o termo "duto espermático" de MCAlPINE (1981) foi mantido, por entendermos que se trata de uma estrutura única.

Tabela I. Terminologia aplicada à espermateca de Bombyliidae.

\begin{tabular}{|c|c|}
\hline Terminologia & Fonte \\
\hline \multicolumn{2}{|c|}{$\begin{array}{l}\text { Bomba de esperma, bes, (sensu YEATES 1994: 123, Fig. = } \\
\begin{aligned} \text { A93, 497) } & \text { (YEATEato ejaculatório da genitália feminina: Theodor, } 1983 \\
& \text { 123), Evenhuis, 1990, Hall \& Evenhuis, } 1987 \text { (YEATES 1994: } \\
= & \text { Aparato muscular: Mühlenberg, 1970 (YEATES 1994: 123). } \\
= & \text { Duto expulsor: ARTIGAS (1971: 5, Fig. 1). }\end{aligned}\end{array}$} \\
\hline \multicolumn{2}{|l|}{$\begin{array}{l}\text { Colares esclerotinizados, ces, (sensu Mühlenberg, } 1970, \\
\text { YEATES 1994: 125): YEATES (1994: 125). }\end{array}$} \\
\hline $\begin{array}{l}\text { Duto comum, duc, (sensu ARTIGAS 1971: 5, Fig. 1): } \\
\text { NAGATOMI \& LIU (1995). }\end{array}$ & = Duto espermático comum: YEATES (1994: 126, Fig.499). \\
\hline \multirow[t]{3}{*}{$\begin{array}{l}\text { Duto espermático, des, (sensu MCALPINE 1981: } 38 \text {, Fig. } \\
\text { 90): YEATES (1994: 125, Fig. 497). }\end{array}$} & = Duto capsular: ARTIGAS (1971: 5, Fig.1). \\
\hline & $\begin{array}{l}=\text { Duto espermático apical: Mühlenberg, } 1970 \text { (YEATES 1994: } \\
\text { 123). }\end{array}$ \\
\hline & $\begin{array}{l}=\text { Duto espermático basal: Mühlenberg, } 1970 \text { (YEATES 1994: } \\
\text { 123). }\end{array}$ \\
\hline \multirow[t]{4}{*}{$\begin{array}{l}\text { Espermateca, ept, [sensu MCALPINE (1981: 38, Fig. 90): } \\
\text { YEATES (1994: 120)]. }\end{array}$} & = Bulbo da espermateca: YEATES (1994: 123, Fig. 493, 497). \\
\hline & = Cápsula: ARTIGAS (1971: 5, Fig. 1), NAGATOMI \& LIU (1995). \\
\hline & $\begin{array}{l}=\text { Cápsula de esperma: Mühlenberg, } 1970 \text { (YEATES 1994: 123), } \\
\text { THEODOR } 1983 \text { (YEATES 1994: 123). }\end{array}$ \\
\hline & $\begin{aligned}= & \text { Reservatório da espermateca: Hall \& Evenhuis, } 1987 \\
& \text { (YEATES 1994: 123), EVENHUIS (1990) (YEATES 1994: } \\
& \text { 123). }\end{aligned}$ \\
\hline Túbulos, tub, (sensu YEATES 1994: 123, Fig. 496, 497) & = Canalículos glandulares: ARTIGAS (1971: 5, Fig. 1) \\
\hline
\end{tabular}

\section{Euprepina Hull, 1971}

Espécie-tipo: Euprepina nuda Hull, 1971 (designação original).

Comprimento total: 9,1-12,8 mm. Machos holópticos; cobertura orogenal castanho polido superiormente e com faixa polinosa prateada acima da inserção dos palpos; palpos com 2 artículos, apresentando fosseta palpal na extremidade do segundo artículo; flagelo pouco maior que escapo e pedicelo juntos, castanho escuro com anel amarelo na base e dois pequenos flagelômeros apicais terminando em um pequeno estilo na ponta; triângulo ocelar castanho, com cerdas castanhas; metanepisterno com longos pêlos na metade posterior, catepisterno com longos pêlos na metade anterior, anepisterno inteiramente recoberto por longos pêlos, metacatepisterno, mero, catepímero e anepímero nus; coxas castanhas com polinosidade cinza; tarsos com cerdas curtas na face ventral; gonocoxa com projeção digitiforme na base; epifalo muito curto, aparecendo em vista lateral como uma pequena projeção triangular; 3 espermatecas de mesmo formato e tamanho; bomba de esperma, com colares esclerotinizados bem desenvolvidos, em cada uma das extremidades, dutos 
espermáticos com o mesmo comprimento, fundindo-se para formar um duto comum; túbulos ausentes.

Caracteres como terminália masculina, espermateca e labelo, foram pela primeira vez utilizados e principalmente as espermatecas, mostraram-se bastante úteis na segregação das espécies.

\section{Chave para identificação das espécies (adultos)}

1. Ápice do abdômen tão largo quanto à base $\ldots \ldots \ldots \ldots \ldots \ldots \ldots \ldots \ldots \ldots$

-. Ápice do abdômen muito mais estreito que a base $\ldots \ldots \ldots \ldots \ldots \ldots \ldots$

2. Veia transversal r-m posicionada no $1 / 4$ distal da célula discal; célula anal aberta na margem da asa a uma distância aproximadamente igual ao tamanho da transversa r-m. [BRAsIl (Mato Grosso, Rio de Janeiro, São Paulo, Santa Catarina e Rio Grande do Sul); ARgENTINA (Tucumán)] .......... E. nuda

-. Veia transversal $\mathrm{r}$-m posicionada no $1 / 3$ distal da célula discal; célula anal aberta na margem da asa em uma distância menor (aproximadamente metade) que o tamanho da transversa r-m [BRASIL (Mato Grosso)] ....... E. maracajula

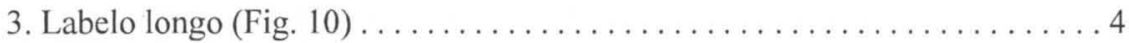

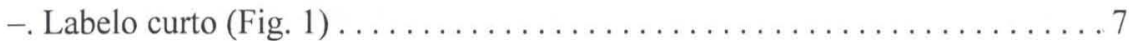

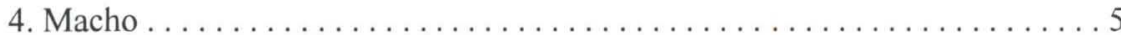

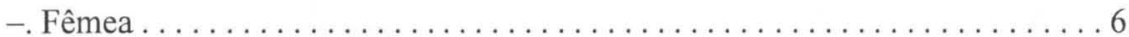

5. Coxas I, II e III com pêlos brancos; tergito V castanho, da mesma cor que os demais tergitos; apódema do edeago lateral longo, ultrapassando a margem

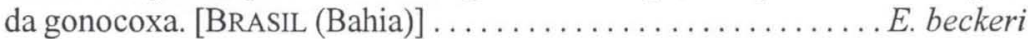

-. Coxas I e II com pêlos castanho avermelhados e coxa III com pêlos brancos; tergito V branco, contrastando com os demais tergitos castanhos; apódema do edeago lateral curto, não ultrapassando a margem da gonocoxa. [BRASIL (Pernambuco, Bahia, Goiás e São Paulo)] ................. E. truxalia

6. Coxas com pêlos brancos; notopleura com três cerdas. [BRAsIL (Bahia)] . . . . . . E. beckeri

-. Coxas com pêlos amarelos; notopleura com cinco cerdas. [BRASIL (Pernambuco, Bahia, Goiás e São Paulo) $\ldots \ldots \ldots \ldots \ldots \ldots \ldots \ldots \ldots$. truxalia

7. Abdômen inteiramente castanho escuro à negro; escapo com menos que o dobro do comprimento do pedicelo. [BRASIL (Rio Grande do Sul)] ... E. caminaria

-. Abdômen com tergitos e/ou manchas brancas; escapo com o dobro ou mais que

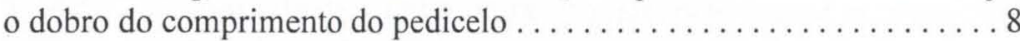

8. Abdômen com tergitos I e II azulados, tergito V branco e tergito IV com uma mancha circular central branca; região do triângulo ocelar com tufo de cerdas. [ARgENTINA (Mendoza)] ..................... E. amabilis

-. Abdômen com outro padrão de coloração; região do triângulo ocelar com cerdas

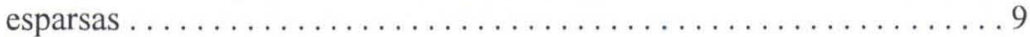


9. Tergito abdominal II com uma larga faixa branca nos $2 / 3$ basais; distifalo longo, ultrapassando o ápice do lobo do gonocoxito; espermateca de comprimento igual ao dobro ou menos que sua largura. [BRASIL (Santa Catarina e Rio Grande do Sul); ArgEnTINA (Jujuy)] .................. E. bicincta -. Tergito abdominal II com uma estreita faixa branca no $1 / 3$ apical; distifalo curto, não ultrapassando o ápice do lobo do gonocoxito; espermateca de comprimento igual ao triplo da largura. [BolíviA (Copinota); ARGENTINA

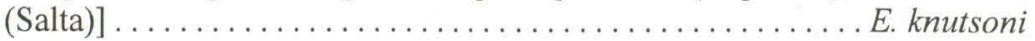

\section{Euprepina nuda Hull, 1971}

Figs $1,2,11,12,13$

Euprepina nuda Hull, 1971; Painter et al., 1978

Euprepina shannoni Hull, 1971; Painter et al., 1978; syn.n.

Material tipo. Holótipo macho (C.N.C.): Brasilien/[Santa Catarina, Seara] Nova Teutonia $/ 27^{\circ} 11^{\prime}$ B-52 23 ' L/Fritz Plaumann/195... [na vertical]/300-500 m [na vertical]; Frank M. Hull/Collection/C.N.C.1973; HOLOTYPE/Euprepina/ nuda Hull/CNC nº 18265 [etiqueta vermelha]; Holotype/Euprepina/nuda/Hull [manuscrito] [etiqueta vermelha]; 35; em bom estado de preservação, com asa esquerda colada.

Alótipo fêmea (C.N.C): Brasilien/[Santa Catarina, Seara] Nova Teutonia/ $27^{\circ} 11^{\prime} \mathrm{B}-52^{\circ} 23^{\prime} \mathrm{L} /$ Fritz Plaumann/195... [na vertical] $/ 300-500 \mathrm{~m}$ [na vertical]; Frank M. Hull/Collection/C.N.C. 1973; Allotype/Euprepina/nuda/Hull [manuscrito] [etiqueta vermelha]; ALLOTYPE/Euprepina [manuscrito]/nuda Hull [manuscrito]/CNC $n^{\circ} 18265$ [etiqueta vermelha]; em bom estado de preservação, faltando: tíbia e tarsos da perna III esquerda; fêmur tíbia e tarsos da perna III direita; pedaço da asa direita que vai desde a margem costal até a célula discal.

Parátipo fềmea (C.N.C.): Brasilien/[Santa Catarina, Seara] Nova Teutonia/ $27^{\circ} 11^{\prime} \mathrm{B}-52^{\circ} 23^{\prime} \mathrm{L} /$ Fritz Plaumann/195... [na vertical]/300 - $500 \mathrm{~m}$ [na vertical]; Frank M. Hull/Collection/C.N.C. 1973; PARATYPE/Euprepina/nuda/Hull [manuscrito] [etiqueta amarela]; em bom estado de preservação, faltando: parte da margem costal da asa esquerda.

Parátipo fêmea (C.N.C.): Brasilien/[Santa Catarina, Seara] Nova Teutonia/ $27^{\circ} 11^{\prime} \mathrm{B}-52^{\circ} 23^{\prime} \mathrm{L} /$ Fritz Plaumann/195... [na vertical] $/ 300$ - $500 \mathrm{~m}$ [na vertical]; Frank M. Hull/Collection/C.N.C. 1973; PARATYPE/Euprepina/nuda/Hull [manuscrito] [etiqueta amarela]; These 2 are/not paratypes [manuscrito] [etiqueta amarela]; em bom estado de preservação, faltando: perna II esquerda e, a direita, já destacada na altura da coxa (mas presa à perna III); metade apical da asa direita.

Diagnose. Probóscide longa, ultrapassando a margem oral em 5/6 do seu comprimento; pedicelo castanho amarelado com cerdas negras do mesmo tamanho ao redor; transversa $\mathrm{r}-\mathrm{m}$ posicionada no $1 / 4$ distal da célula discal; abdômen com ápice de largura semelhante a base, nos machos, negro com tergito $\mathrm{V}$ branco, nas fêmeas castanho claro; gonocoxa com extremo ápice voltado para frente; distifalo curto, terminando antes do ápice dos lobos do gonocoxito; apódema do edeago lateral curto, com ápice terminando antes da margem externa da gonocoxa em vista dorsal; espermateca alongada, sem membranas ao redor da base; dutos espermáticos largos. 

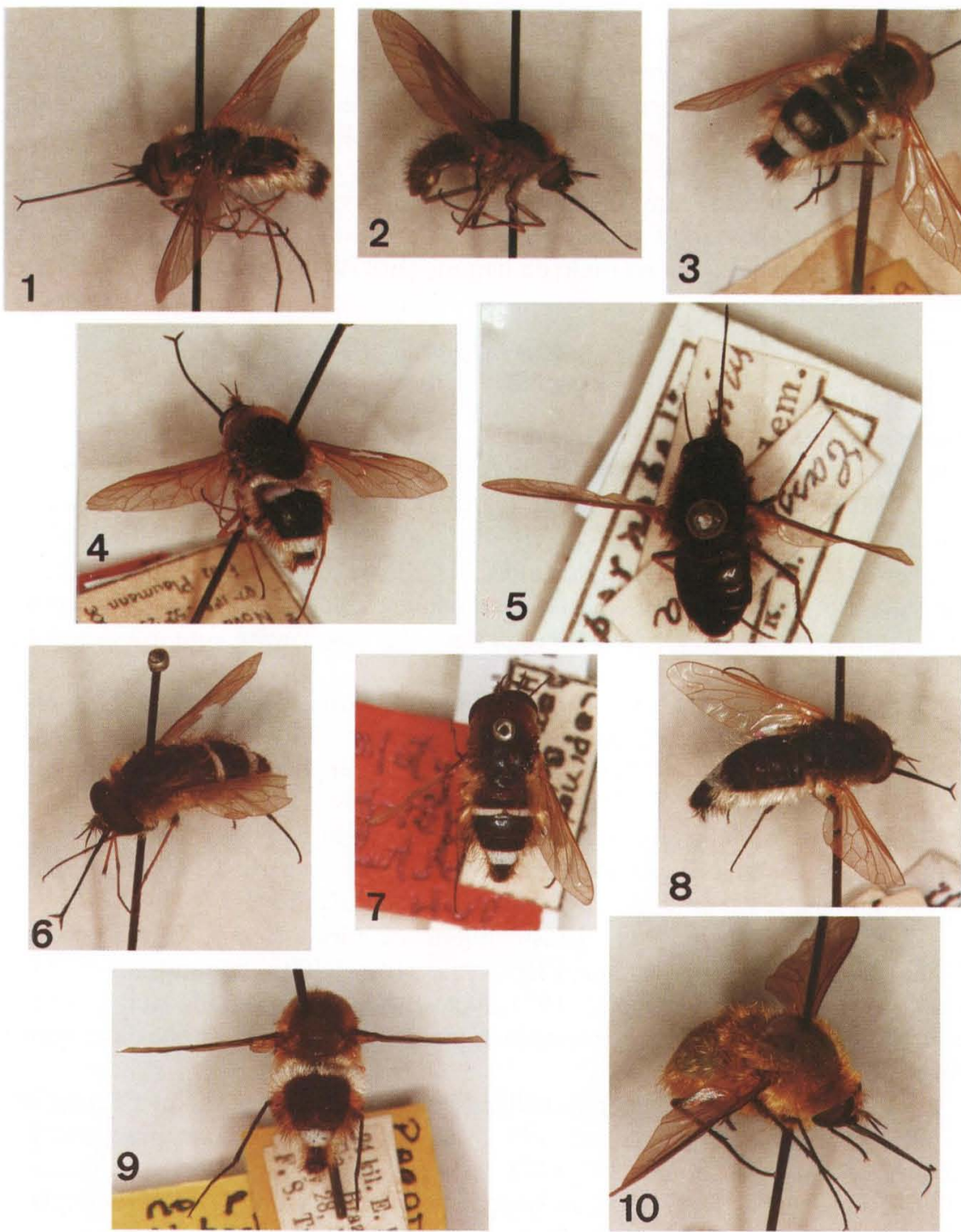

Figs 1-10. (1-2) Euprepina nuda: (1) holótipo macho; (2) parátipo fêmea; (3) Euprepina amabilis, macho; (4) Euprepina bicincta, macho; (5) Euprepina caminaria, lectótipo macho; (6-7) Euprepina knutsoni, holótipo macho; (8) Euprepina maracajula, holótipo macho; (9-10) Euprepina truxalia: (9) parátipo macho; (10) parátipo fêmea.

Macho (Fig. 1). Comprimento - corpo: 8,7-9,2 mm; asa: 7,6-8,6 mm.

Cabeça. Fronte castanho escura; face castanho escura com polinosidade prateada na parte inferior; palpo de tamanho equivalente a $1 / 6$ do tamanho da probóscida, castanho escuro com base castanho clara, com cerdas amarelas na metade basal e castanho escuro na apical; probóscida ultrapassando a margem oral 
em 5/6 do seu comprimento; labelo curto; antenas com escapo castanho escuro com polinosidade cinza, com o dobro do comprimento do pedicelo, com cerdas negras ao redor, mais longas lateralmente e abaixo; pedicelo castanho amarelado com cerdas negras do mesmo tamanho ao redor; triângulo ocelar com muitas cerdas de tamanho semelhante; occipício castanho com polinosidade cinza, com pêlos amarelos.

Tórax. Dorso negro revestido com pêlos amarelo-pálidos; metanepisterno com longos pêlos amarelo-pálidos na metade posterior, catepisterno com longos pêlos amarelo-pálidos na metade anterior, anepisterno inteiramente recoberto por longos pêlos amarelo-pálidos; notopleura com três cerdas; calo pós-alar com longos pêlos branco amarelados; halter amarelo; calíptras com pêlos brancos na margem. Pernas: fêmures castanhos e tíbias castanho amareladas; fêmures com escamas brancas e tíbias I e II com escamas brancas e pretas vistas sob certa iluminação, e tíbia III com escamas pretas. Perna I: coxa com longos pêlos brancos; fêmur com cerdas brancas longas e finas na face ventral, mais concentradas nos $2 / 3$ basais; tíbia com cerdas curtas espaçadas nas faces ântero-ventral, ântero-dorsal, póstero-ventral e póstero-dorsal; faces ântero-dorsal, póstero-dorsal, póstero-ventral e ventral com uma cerda apical, a última mais longa; tarso com cerdas curtas na face ventral; pré-tarso longo de tamanho equivalente a soma dos demais segmentos tarsais; unhas castanho claras com ápice negro e pulvilo de comprimento aproximadamente igual a unha. Perna II: coxa com longos pêlos brancos; fêmur com cerdas brancas longas e finas na face ventral, mais concentradas nos $2 / 3$ basais; tíbia com cerdas curtas espaçadas nas faces ântero-ventral, ântero-dorsal, póstero-ventral e póstero-dorsal; 3 cerdas no 1/3 médio face posterior; faces ântero-dorsal, póstero-dorsal, pósteroventral e ventral com uma cerda apical, a última mais longa; tarso com cerdas curtas na face ventral; pré-tarso, unhas e pulvilos como na perna anterior. Perna III: coxa com longos pêlos brancos; fêmur na face ventral com cerdas brancas longas e finas, aproximadamente na metade basal e negras na apical; tíbia com cerdas curtas espaçadas nas faces ântero-ventral, ântero-dorsal, póstero-ventral e póstero-dorsal, mais desenvolvidas na primeira; faces ântero-dorsal, póstero-dorsal, póstero-ventral e ventral com uma cerda apical, a última mais longa; tarso com cerdas curtas na face ventral; pré-tarso longo, medindo um pouco menos que a soma dos demais segmentos tarsais; unhas e pulvilos como na perna anterior. Asa: hialina com margem costal levemente tingida de castanho. Célula r5 largamente aberta na margem da asa, em uma distância maior que o tamanho da transversa r-m, célula anal aberta na margem da asa em uma distância aproximadamente igual ao tamanho da transversa r-m; transversa r-m posicionada no 1/4 distal da célula discal deixando célula br com o dobro do tamanho da célula bm.

Abdômen. Com ápice de largura semelhante à base, negro revestido com longos pêlos amarelos mais abundantes lateralmente até o segmento $\mathrm{V}$, do segmento VI até o ápice, revestido por longos pelos castanho avermelhados, tergito $\mathrm{V}$ branco.

Terminália (Figs 11, 12). Gonocoxa alta em vista lateral com extremo ápice arredondado, voltado para frente; distifalo curto, terminando antes do ápice dos lobos do gonocoxito; apódema do edeago lateral curto, com ápice terminando antes da margem externa da gonocoxa em vista dorsal; apódema ejaculatório com ápice afilado. 


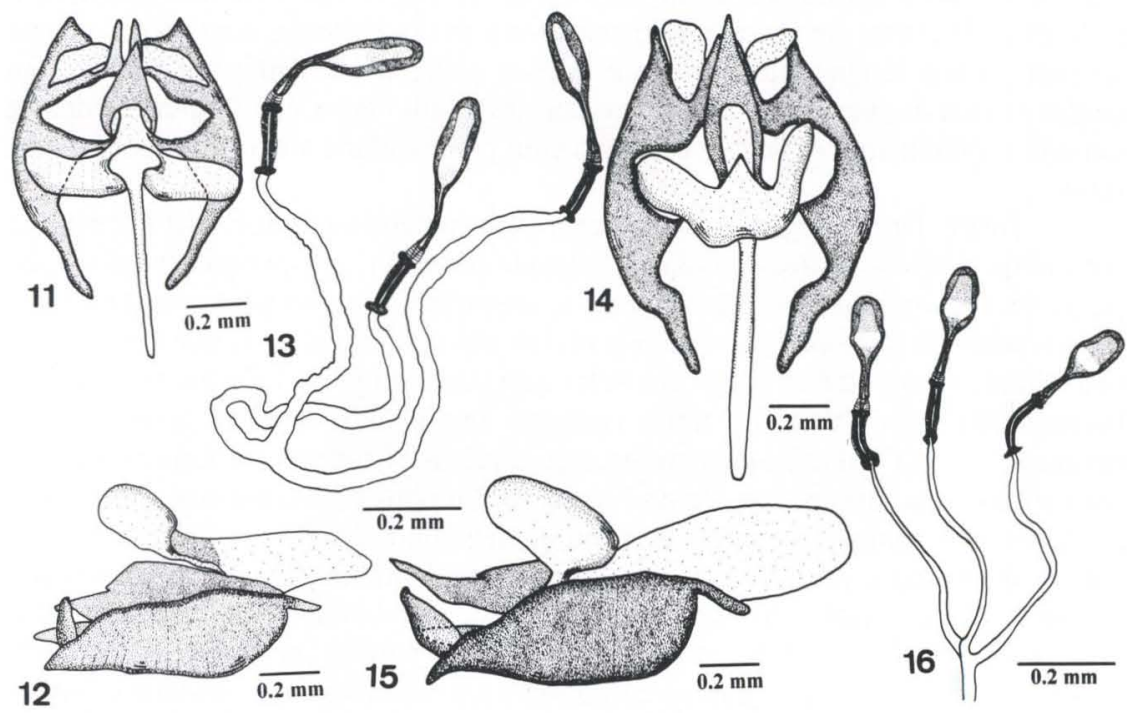

Figs 11-16. (11-13) Euprepina nuda: (11) terminália masculina, vista dorsal; (12) terminália masculina, vista lateral; (13) espermateca; (14-16) Euprepina bicincta: (14) terminália masculina, vista dorsal; (15) terminália masculina, vista lateral; (16) espermateca.

Fêmea (Fig. 2). Comprimento - corpo: 8,7-9,1 mm; asa: 9,1-9,5 mm.

Semelhante ao macho, diferindo no que segue.

Cabeça. Fronte e face castanho claras.

Abdômen. Castanho claro recoberto por pêlos amarelos e longas cerdas castanho escuras.

Espermateca (Fig. 13). Espermateca alongada, sem membrana ao redor da base; dutos espermáticos largos, cinco vezes mais longos que as espermatecas.

Material examinado. BRAsil, Mato Grosso: Maracajú, V.1937, 4 machos e 5 fêmeas, Serviço Febre Amarela, M.E.S. leg. (MZUSP); Minas Gerais: Poços de Caldas (Morro do Ferro), 27.I.1965, 1 macho, J. Becker, O. Roppa, O. Leoncini leg. (MNRJ); 22.III.1966, 2 machos e 2 fêmeas, O. Roppa leg. (MNRJ); 24.III.1966, 7 machos, J. Becker \& O. Roppa leg. (MNRJ); 24.IV.1966, 3 machos, O. Roppa \& O. Leoncini leg. (MNRJ); XI. 1971, 1 macho e 1 fêmea, J. Becker \& O. Roppa leg. (MNRJ); Rio de Janeiro, Alto Itatiaia, alt. 2000m, III.1941, 8 machos, (1 macho, holótipo de E. shannoni) R.C. Shannon \& L. Gômes leg. (MZUSP); São Paulo, Batatais, III.1943, 8 machos e 1 fêmea, A. Stafuzza leg. (MZUSP); IV.1945, 7 machos e I fềmea, Pe. Pereira leg. (MZUSP); Campos do Jordão, III.1945, 1 macho, Ramalho leg. (MZUSP); Campos do Jordão, III. 1946, 1 macho, E. Ribas leg. (MZUSP); Campos do Jordão (1650m, Fazenda da Guarda, Alto da Boa Vista), 
23.III.1963, 4 machos e 1 fêmea, Rabello, Travassos Filho, J. Guimarães \& Barroso leg. (MZUSP); 31.III.1963, 9 machos e 2 fềmeas, Rabello, Travassos Filho, J. Guimarães \& Barroso leg. (MZUSP); Campos do Jordão, 15.III.1972, 1 fêmea, E. Ribas leg. (MZUSP); Campos do Jordão (1600 m), III.1945, 8 machos e 4 fêmeas, Wygodzinsky leg. (MNRJ); Ypiranga, 30.III.1936, 1 macho e 2 fêmeas, Lange de Morretes leg. (MNRJ); 31.III.1936, 3 machos e 2 fêmeas, Lange de Morretes leg. (MNRJ); 1.IV.1936, 1 macho e 3 fêmeas, Lange de Morretes leg. (MNRJ); 2.IV.1936, 1 macho e 1 fêmea, Lange de Morretes leg. (MNRJ); 3.IV.1936, 4 machos e 4 fềmeas, Lange de Morretes leg. (MNRJ); 8.IV.1936, 3 machos e 3 fêmeas, Lange de Morretes leg. (MNRJ);28.III.1937, 2 machos, Lange de Morretes leg. (NMNH); Rio Grande do Sul: Bagé, 27.II.1961, 2 machos e 3 fêmeas, (NMNH); 28.II.1961, 4 fêmeas, (NMNH); 1.III.1961, 3 machos e 1 fềmea, (NMNH). ARGENTINA, Tucumán: (RT-341, 14 KM WSW Jet. RT. 9), 23-24.III.1992, 2 machos, P. de Vries, O. Di Iorio, E. Quinter \& D. Yeates leg. (UQIC).

Registro geográfico. Brasil (Mato Grosso, Rio de Janeiro, São Paulo, Santa Catarina e Rio Grande do Sul), Argentina (Tucumán).

\section{Euprepina amabilis (Wulp, 1881)}

\section{Fig. 3}

Dischistus amabilis Wulp, 1881

Sparnopolius amabilis; Painter \& Painter, 1974

Euprepina amabilis; Painter et al., 1978

Diagnose. Fêmur III com pêlos brancos nas faces ântero-ventral e ventral e fileira de cerdas negras fortes no $1 / 3$ apical da face ventral; abdômen com ápice muito mais estreito que a base; castanho escuro com tergitos I e II azulados, tergito IV com uma mancha circular central branca e tergito $\mathrm{V}$ branco.

Macho (Fig. 3): comprimento: corpo: 10, $8 \mathrm{~mm}$; asa: 9,7 mm.

Cabeça. Fronte castanho escura; face castanho escura com polinosidade prateada mais intensa na parte inferior; palpo de tamanho equivalente a $1 / 6$ do tamanho da probóscida sem o labelo, castanho escuro com cerdas brancas ao redor; probóscida excedendo a margem oral em $5 / 6$ do seu comprimento; labelo curto; antenas com escapo castanho escuro com polinosidade cinza, com o dobro do comprimento do pedicelo, com cerdas negras ao redor, mais longas lateralmente e abaixo; pedicelo castanho escuro com polinosidade cinza e ápice amarelo com cerdas negras do mesmo tamanho ao redor; (flagelos quebrados nos dois exemplares); triângulo ocelar com muitas cerdas de tamanhos variados; occipício branco com pêlos amarelos.

Tórax. Castanho dorsalmente e com polinosidade azul esverdeada lateralmente, coberto por longos pêlos amarelos; pleuras com polinosidade azul esverdeada, metanepisterno com longos pêlos amarelos na metade póstero-superior; catepisterno com pêlos amarelos nos $2 / 3$ anteriores, anepisterno inteiramente recoberto por longos pêlos amarelos; notopleura com quatro cerdas; calo pós-alar com longos pêlos brancos; halter com haste castanho clara e capítulo amarelo. Pernas: fềmures 
e tíbias castanhos com escamas amarelas. Perna I: coxa com longos pêlos brancos; fêmur com pêlos brancos na face ventral; tíbia com cerdas curtas espaçadas nas faces ântero-ventral, ântero-dorsal, póstero-ventral e póstero-dorsal; faces ântero-dorsal, póstero-dorsal, póstero-ventral e ventral com uma cerda apical, a última mais longa; tarso com cerdas curtas na face ventral; pré-tarso longo de tamanho equivalente a soma dos demais segmentos tarsais; unhas castanho escuras com ápice negro e pulvilo de comprimento aproximadamente igual a unha. Perna II: coxa com longos pêlos brancos; fêmur com pêlos brancos nas faces ântero-ventral, ventral e pósteroventral; tíbia com cerdas curtas espaçadas nas faces ântero-ventral, ântero-dorsal, póstero-ventral e póstero-dorsal; faces ântero-dorsal, póstero-dorsal, póstero-ventral e ventral com uma cerda apical, a última mais longa; tarso, pré-tarso, unhas e pulvilos como na perna anterior. Perna III: coxa com longos pêlos brancos; fêmur com pêlos brancos nas faces ântero-ventral e ventral e fileira de cerdas negras fortes no $1 / 3$ apical da face ventral; tíbia com cerdas curtas espaçadas nas faces ânteroventral, ântero-dorsal, póstero-ventral e póstero-dorsal; faces ântero-dorsal, póstero-dorsal, póstero-ventral e ventral com uma cerda apical, a última mais longa; tarso com cerdas curtas na face ventral; pré-tarso longo medindo um pouco menos que a soma dos demais segmentos tarsais; unhas e pulvilos como na perna anterior. Asa: hialina; célula r5 aberta na margem da asa em uma distância aproximadamente igual ao tamanho da transversa $\mathrm{r}-\mathrm{m}$; célula anal aberta na margem da asa em uma distância equivalente a metade do tamanho da transversa $\mathrm{r}-\mathrm{m}$; transversa $\mathrm{r}-\mathrm{m}$ posicionada no 1/4 distal da célula discal, deixando a célula br com o dobro do comprimento da célula bm.

Abdômen. Com base muito mais larga que o ápice, castanho escuro; tergitos I e II azulados, tergito IV com uma mancha circular central branca e tergito V branco; tergitos III e IV com mancha branca lateralmente; abdômen revestido lateralmente com pêlos brancos nos tergitos I, II e V, e pêlos castanho avermelhados nos demais tergitos; branco com polinosidade azul esverdeada ventralmente e recoberto por pêlos brancos.

Material examinado. ARgENTINA: 2 machos (ITZA).

Registro geográfico. Argentina (Mendoza).

Comentários. Fêmea desconhecida. Não foi autorizada a dissecção da terminália dos exemplares.

\section{Euprepina beckeri Lamas \& Couri, 1998}

LAMAS \& COURI (1998) acrescentaram recentemente esta espécie ao gênero.

Diagnose. Labelo longo; occipício negro, com polinosidade cinza e pêlos amarelos; unhas castanho escuras; abdômen negro, com densos pêlos brancos na metade basal do tergito II; distifalo longo, terminando após o ápice dos lobos do gonocoxito; apódema do edeago lateral longo, com ápice excedendo a margem externa da gonocoxa em vista dorsal; espermateca oval, com uma membrana ao redor da base. 


\section{Euprepina bicincta (Wiedemann, 1830)}

Figs $4,14,15,16$

Bombylius bicinctus Wiedemann, 1830

Sparnopolius bicinctus; Hull, 1973; Painter \& Painter, 1974; Lectotipo

Euprepina bicincta Hull, 1971 (nec Wiedemann, 1830); Painter et al.,1978; syn. n. Euprepina bicincta [sic] Wiedemann, 1830; Painter et al., 1978.

Material tipo. Lectótipo macho (NMW): Cassapawa [manuscrito]; bicinctus [manuscrito]/Coll. Wiedem.; B. bicinctus/Wied./Lectotype [sublinhado de vermelho]/1960 [manuscrito]/Det. R. H. Painter; em bom estado de conservação, com escudo parcialmente destruído e asa direita danificada no ápice; faltando: tarsos da perna I direita e esquerda e tarso esquerdo da perna II.

Diagnose. Abdômen com ápice muito mais estreito que a base, negro com tergito II com larga faixa branca basal com uma concavidade no centro; tergito $\mathrm{V}$ inteiramente branco; distifalo longo, terminando após o ápice dos lobos do gonocoxito; apódema do edeago lateral curto, com ápice terminando antes da margem externa da gonocoxa em vista dorsal; espermateca oval com uma projeção lateral na metade basal, sem membrana ao redor da base.

Macho (Fig. 4): comprimento: corpo: 9,1-12,8 mm; asa: 9,1-9,5 mm.

Cabeça. Fronte castanho escura; face castanho escura com polinosidade prateada na parte inferior; palpo de tamanho equivalente a 1/6 do comprimento da probóscida, castanho escuro com base castanha com cerdas amarelas na metade basal e castanho escuras na apical; probóscida ultrapassando a margem oral em 5/6 do seu comprimento; labelo curto; antenas com escapo castanho escuro com polinosidade cinza, um pouco maior que o pedicelo com longas cerdas negras ao redor, mais longas lateralmente e abaixo; pedicelo castanho amarelado com cerdas negras mais longas lateralmente e abaixo; triângulo ocelar com poucas cerdas de tamanhos variados; occipício castanho escuro com pequena faixa de polinosidade prateada lateralmente junto aos olhos, com pêlos amarelo avermelhados.

Tórax. Dorso negro com pêlos amarelos; metanepisterno com longos pêlos amarelos na metade posterior; catepisterno com pêlos castanhos e amarelos misturados na metade anterior; anepisterno inteiramente recoberto por longos pêlos castanhos e amarelos avermelhados e cerdas castanho escuras na parte superior; notopleura com quatro cerdas; calo pós-alar com cerdas castanho escuras; halter com haste castanho clara e capítulo castanho mais escuro; calíptras com pêlos castanho escuros na margem. Pernas: fêmures, tíbias e tarsos castanho amarelados. Perna I: coxa com longos pêlos castanho amarelados; fêmur com cerdas negras longas e finas na face ventral, mais concentradas nos $2 / 3$ basais; tíbia com cerdas curtas espaçadas nas faces ântero-ventral, ântero-dorsal, póstero-ventral e pósterodorsal; faces ântero-dorsal, póstero-dorsal, póstero-ventral e ventral com uma cerda apical, a última mais longa; tarso com cerdas curtas na face ventral; pré-tarso longo de tamanho equivalente a soma dos demais segmentos tarsais; unhas castanho claras com ápice negro e pulvilo de comprimento aproximadamente igual a unha. Perna II: coxa com longos pêlos castanho escuros; fêmur na face ventral com fileira de cerdas negras de comprimento irregular, curtas e finas em toda extensão; tíbia com 
cerdas curtas espaçadas nas faces ântero-ventral, ântero-dorsal, póstero-ventral e póstero-dorsal; três cerdas no 1/3 médio face posterior; faces ântero-dorsal, póstero-dorsal, póstero-ventral e ventral com uma cerda apical, a última mais longa; tarsos, unhas e pulvilos como na perna anterior. Perna III: coxa com longos pêlos amarelos e castanho escuros; fêmur na face ventral com fileira de cerdas negras de comprimento irregular curtas e finas em toda extensão; tíbia com cerdas curtas espaçadas nas faces ântero-ventral, ântero-dorsal, póstero-ventral e póstero-dorsal, mais desenvolvidas na primeira; faces ântero-dorsal, póstero-dorsal, póstero-ventral e ventral com uma cerda apical, a última mais longa; tarso com cerdas curtas na face ventral; pré-tarso longo, medindo um pouco menos que a soma dos demais segmentos tarsais; unhas e pulvilos como na perna anterior. Asa: hialina levemente tingida de castanho na base e uma área que vai desde a margem costal até a célula br (inclusive); célula rs largamente aberta na margem da asa, em uma distância pouco maior que o tamanho da transversa $\mathrm{r}-\mathrm{m}$, célula anal aberta na margem da asa em uma distância aproximadamente igual ao tamanho da transversa $\mathrm{r}-\mathrm{m}$; transversa $\mathrm{r}-\mathrm{m}$ posicionada no $1 / 3$ distal da célula discal, deixando a célula br $1 / 3$ maior que a célula bm.

Abdômen. Com ápice muito mais estreito que a base, negro, com tergito II com uma larga faixa branca basal com uma concavidade no centro, tergito $\mathrm{V}$ inteiramente branco, revestido com pêlos brancos no tergito I, na área branca do tergito II e no tergito V; segmentos III e IV lateralmente com pêlos castanho avermelhados superiormente e brancos inferiormente; restante do dorso com pêlos castanho avermelhados e todo o ventre com pêlos brancos.

Terminália (Figs 14, 15): gonocoxa alta em vista lateral com extremo ápice afilado e voltado para baixo; distifalo longo, terminando após o ápice dos lobos do gonocoxito; apódema do edeago lateral curto, com ápice terminando antes da margem externa da gonocoxa em vista dorsal; apódema ejaculatório com margem arredondada em vista lateral.

Fêmea. Comprimento - corpo: 9,7-9,9 mm; asa: 9,8-10,9 mm.

Semelhante ao macho, diferindo no que segue.

Cabeça. Fronte castanho escura com polinosidade prateada desde o triângulo ocelar até o nível da inserção das antenas; escapo castanho com polinosidade cinza, com cerdas negras curtas superiormente e lateralmente, e cerdas longas amarelo avermelhadas inferiormente.

Tórax. Dorso castanho, revestido com pêlos amarelo avermelhados; catepisterno com pêlos amarelos na metade anterior; anepisterno inteiramente recoberto por longos pêlos amarelos e com cerdas castanho escuras na parte superior. Pernas: coxa I e II recoberta por pêlos amarelos ao redor e cerdas castanhas na face anterior; coxa III recoberta por pêlos amarelos.

Abdômen. Castanho, tergito V castanho; segmento III revestido com pêlos castanho avermelhados lateralmente e o restante com pêlos brancos e esparsas cerdas castanhas.

Espermateca (Fig. 16). Oval com uma projeção lateral na metade basal, sem membrana ao redor da base; dutos espermáticos finos, quatro vezes mais longos que as espermatecas. 
Material examinado. BRASIL, Santa Catarina: Seara (Nova Teutônia), X.1948, 1 macho, F. Plaumann leg. (MZUSP); XI.1948, 4 fềmeas, F. Plaumann leg. (MZUSP); $27^{\circ} 11^{\prime} \mathrm{B}-52^{\circ} 23^{\prime} \mathrm{L}$ 300-500 m, 195?, 1 macho e 3 fềmeas, Fritz Plaumann leg. (C.N.C.); X.1970, 2 machos e 1 fềmea, F. Plaumann, leg. (MZUSP); Rio Grande do Sul: Stieglmayr col. (Homótipo), Pelotas, 13.X.1961, 1 fêmea, C.M. Biezanko leg. (MZUSP); 16.X.1961, 1 fêmea, C.M. Biezanko leg. (MZUSP); 26.X.1961, 1 macho, C.M. Biezanko leg. (MZUSP); 29.X.1961, 1 macho, C.M. Biezanko leg. (MZUSP); São Jerônimo, XI.1952, 3 machos e 2 fêmeas, Pe. Pereira leg. (MZUSP). ARgentina, Jujuy: (2040m, Dept. Ticara, S Volcan Paramo \& Boulder Fields), 7-9.IV.1992, 1 fêmea, P. De Vries, O. Di Iorio, E. Quinter \& D. Yeates leg. (UQIC); Jujuy 1750m, Baptist Center Nr. Rio Lozano, N Slope and Summit, 10.IV.1992, 1 macho, P. De Vries, O. Di Iorio, E. Quinter \& D. Yeates (UQIC). (Jujuy).

Registro geográfico. Brasil (Santa Catarina, Rio Grande do Sul), Argentina

\section{Euprepina caminaria (Wiedemann, 1830)}

Figs $5,17,18$

\section{Bombylius caminarius Wiedemann, 1830}

Sparnopolius caminarius; Hull, 1973; Painter \& Painter, 1974; Lectotipo

Euprepina caminaria; Painter et al., 1978

Material tipo. Lectótipo macho (NWM): Cassapawa; caminarius/Coll Wiedem.; Sparnopolius/caminarius/Wied./Lectotype [sublinhado de vermelho]/ 1960 [manuscrito]/Det. R. H. Painter; em bom estado de preservação; asa direita com veia marginal quebrada na base; escudo um pouco danificado pelo alfinete.

Diagnose. Abdômen com ápice muito mais estreito que a base, inteiramente castanho escuro; gonocoxa com extremo ápice voltado para frente; distifalo longo, terminando após o ápice dos lobos do gonocoxito; apódema do edeago lateral longo, com ápice ultrapassando a margem externa da gonocoxa em vista dorsal.

Macho (Fig. 5): comprimento: corpo: $9,8 \mathrm{~mm}$; asa: $9,8 \mathrm{~mm}$.

Cabeça: fronte castanho escura; face castanho escura com polinosidade prateada na parte inferior; palpo de tamanho equivalente a $1 / 5$ do tamanho da probóscida, castanho escuro com pêlos castanho escuros ao redor; probóscida ultrapassando a margem oral em 4/5 do seu tamanho; labelo curto; antenas com escapo castanho escuro com polinosidade cinza, um pouco maior que o pedicelo, com cerdas negras ao redor, mais longas lateralmente e abaixo; pedicelo castanho escuro, com polinosidade cinza e extremo ápice amarelo, com cerdas negras mais longas lateralmente e abaixo; triângulo ocelar com poucas cerdas de tamanho variado; occipício castanho escuro, com pêlos castanho escuros.

Tórax. Dorso castanho escuro revestido com pêlos castanho escuros e amarelo avermelhados; metanepisterno com pêlos castanhos na metade posterior; catepisterno com pêlos castanhos longos e finos na metade anterior; anepisterno inteiramente recoberto por cerdas castanhas e com longos pêlos amarelo avermeIhados junto ao canto póstero-superior; calo pós-alar com cerdas castanho escuras; halter castanho escuro com capítulo castanho escuro; calíptras com pêlos castanho 


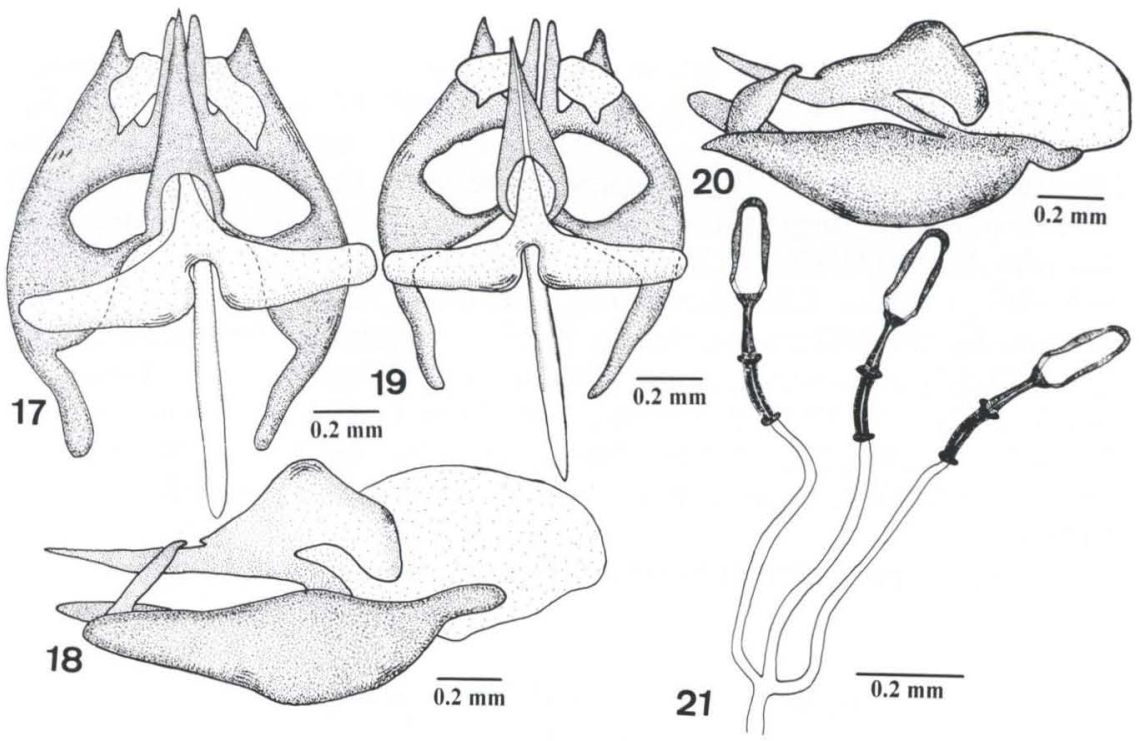

Figs 17-21. (17-18) Euprepina caminaria: (17) terminália masculina, vista dorsal; (18) terminália masculina, vista lateral; (19-21) Euprepina knutsoni: (19) terminália masculina, vista dorsal; (20) terminália masculina, vista lateral; (21) espermateca.

escuros na margem. Pernas: fêmures castanhos com polinosidade cinza exceto no ápice que é castanho amarelado; fêmures e tíbias com escamas brancas. Perna I": coxa com longos pêlos castanho escuros; fêmur com pêlos castanho escuros na face ventral; tíbia com cerdas curtas espaçadas nas faces ântero-ventral, ântero-dorsal, póstero-ventral e póstero-dorsal; faces ântero-dorsal, póstero-dorsal, póstero-ventral e ventral com uma cerda apical, a última mais longa; tarso com cerdas curtas na face ventral; pré-tarso longo de tamanho equivalente a soma dos demais segmentos tarsais; unhas castanho claras com ápice negro e pulvilo de comprimento aproximadamente igual a unha. Perna II: coxa com longos pêlos castanho escuros; fêmur com pêlos castanho escuros nas faces ântero-ventral e póstero-ventral; tíbia com cerdas curtas espaçadas nas faces ântero-ventral, ântero-dorsal, póstero-ventral e póstero-dorsal; faces ântero-dorsal, póstero-dorsal, póstero-ventral e ventral com uma cerda apical, a última mais longa; tarso, unhas e pulvilos como na perna anterior. Perna III: coxa com longos pêlos castanho escuros; fêmur com pêlos castanho escuros na face ventral; tíbia com cerdas curtas espaçadas nas faces ântero-ventral, ântero-dorsal, póstero-ventral e póstero-dorsal; faces ântero-dorsal, póstero-dorsal, póstero-ventral e ventral com uma cerda apical, a última mais longa; tarso com cerdas curtas na face ventral; pré-tarso longo, medindo um pouco menos que a soma dos demais segmentos tarsais; unhas e pulvilos como na perna anterior. Asa: hialina levemente castanho na base e margem anterior; célula r5 aberta na margem da asa em uma distância aproximadamente igual ao tamanho da transversa $\mathrm{r}$-m; célula anal aberta na margem da asa em uma distância menor que o tamanho da transversa $\mathrm{r}-\mathrm{m}$; transversa $\mathrm{r}-\mathrm{m}$ posicionada no $1 / 3$ distal da célula discal, deixando a célula br $1 / 3$ maior que a célula bm. 
Abdômen. Com ápice muito mais estreito que a base, castanho escuro à negro, com pêlos castanho escuro avermelhados lateralmente. $\mathrm{O}$ único exemplar examinado encontra-se sem pêlos no abdômen dorsalmente.

Terminália (Figs 17, 18). Gonocoxa estreita em vista lateral, com extremo ápice arredondado voltado para frente; distifalo longo, terminando após o ápice dos lobos do gonocoxito; apódema do edeago lateral longo, com ápice ultrapassando a margem externa da gonocoxa em vista dorsal; apódema ejaculatório com margem inferior projetada em vista lateral.

Registro geográfico. Brasil (Rio Grande do Sul).

Comentários. Fêmeas não examinadas.

\section{Euprepina knutsoni Hull, 1971}

Figs $6,7,19,20,21$

Euprepina knutsoni Hull, 1971; Painter et al., 1978

Material tipo. Holótipo macho (NMNH): Copinota/Bolivia/.... (?) 1918/H. Mejubla [manuscrito]; Holotype/Euprepina/Knutsoni/Hull [manuscrito] [etiqueta vermelha]; em bom estado de conservação, com lado direito do escudo e escutelo parcialmente destruídos, faltando: tarso II direito; parte da asa direita que engloba as células axilar, anal e quarta posterior e margem costal e ápice da asa esquerda.

Diagnose. Asa hialina, levemente avermelhada com aspecto aveludado; abdômen com ápice muito mais estreito que a base; negro com tergito II apresentando uma faixa branca estreita com uma concavidade no centro situada na metade apical, tergito $\mathrm{V}$ inteiramente branco; distifalo curto, terminando junto ao ápice dos lobos do gonocoxito; apódema do edeago lateral longo, com ápice ultrapassando a margem externa da gonocoxa em vista dorsal; espermateca alongada com projeção lateral na metade basal e uma invaginação na metade apical, sem membrana ao redor da base.

Macho (Figs 6, 7). Comprimento - corpo: 9,1-10,0 mm; asa: 8,12-8,9 mm.

Cabeça. Fronte castanho escura; face castanho escura com polinosidade prateada na parte inferior; palpo de tamanho equivalente a $1 / 6$ do tamanho da probóscida, castanho escuro com base castanha com cerdas amarelas na metade basal e negras na apical; probóscida ultrapassando a margem oral em 5/6 do seu comprimento; labelo curto; antenas com escapo castanho escuro com polinosidade cinza, com o dobro do comprimento do pedicelo, com cerdas negras ao redor, mais longas lateralmente e abaixo; pedicelo castanho amarelado com cerdas negras do mesmo tamanho ao redor; triângulo ocelar com poucas cerdas de tamanho semelhante; occipício castanho escuro com pequena faixa de polinosidade prateada lateralmente junto aos olhos, com pêlos amarelo avermelhados.

Tórax. Dorso negro com pêlos amarelo avermelhados; metanepisterno com longos pêlos amarelos na metade posterior; catepisterno com pêlos amarelos na metade anterior; anepisterno inteiramente recoberto por longos pêlos castanhos e amarelos avermelhados; notopleura com três cerdas; calo pós-alar com cerdas castanho escuras; halter com haste castanho clara e capítulo amarelo com mancha 
castanho escura na face ventral; calíptras com pêlos amarelos na margem. Pernas: fêmures castanhos com ápice castanho amarelado, tíbias e tarsos castanho amarelados; fêmures com escamas branco amareladas. Perna I: coxa com longos pêlos brancos na face anterior; fêmur com cerdas brancas longas e finas na face ventral, mais concentradas nos $2 / 3$ basais; tíbia com cerdas curtas espaçadas nas faces ântero-ventral, ântero-dorsal, póstero-ventral e póstero-dorsal; faces ântero-dorsal, póstero-dorsal, póstero-ventral e ventral com uma cerda apical, a última mais longa; tarso com cerdas curtas na face ventral; pré-tarso longo de tamanho equivalente a soma dos demais segmentos tarsais; unhas castanho claras com ápice negro e pulvilo de comprimento aproximadamente igual a unha. Perna II: coxa com longos pêlos brancos na face anterior; fêmur com cerdas brancas longas e finas na face ventral, mais concentradas nos $2 / 3$ basais; tíbia com cerdas curtas espaçadas nas faces ântero-ventral, ântero-dorsal, póstero-ventral e póstero-dorsal; faces ântero-dorsal, póstero-dorsal, póstero-ventral e ventral com uma cerda apical, a última mais longa; tarso, pré-tarso, unhas e pulvilos como na perna anterior. Perna III: coxa com longos pêlos brancos; fêmur na face ventral com cerdas brancas longas e finas, aproximadamente na metade basal e negras na apical; tíbia com cerdas curtas espaçadas nas faces ântero-ventral, ântero-dorsal, póstero-ventral e póstero-dorsal; faces ânterodorsal, póstero-dorsal, póstero-ventral e ventral com uma cerda apical, a última mais longa; pré-tarso longo, medindo um pouco menos que a soma dos demais segmentos tarsais; tarso, unhas e pulvilos como na perna anterior. Asa: hialina, levemente avermelhada com aspecto aveludado, fracamente tingida de castanho na base desde a margem costal até a célula br (inclusive); célula r5 largamente aberta na margem da asa, em uma distância aproximadamente igual ao comprimento da transversa r-m; célula anal aberta na margem da asa em uma distância aproximadamente igual ao tamanho da transversa $\mathrm{r}-\mathrm{m}$; transversa $\mathrm{r}-\mathrm{m}$ posicionada no $1 / 4$ distal da célula discal deixando a célula br com o dobro do tamanho da célula bm.

Abdômen: com ápice muito mais estreito que a base, negro, tergito II com uma estreita faixa branca na metade apical com uma concavidade no centro; tergito $\mathrm{V}$ inteiramente branco; dorso revestido com pêlos amarelo avermelhados; segmentos I, II e V revestidos com pêlos amarelos lateralmente, os demais com pêlos castanhos, ventre revestido com pêlos amarelos.

Terminália (Figs 19,20). Gonocoxa baixa em vista lateral com extremo ápice afilado e voltado para baixo; distifalo curto, terminando junto com o ápice dos lobos do gonocoxito; apódema do edeago lateral longo, com ápice ultrapassando a margem externa da gonocoxa em vista dorsal; apódema ejaculatório com margem regular em vista lateral.

Fêmea. Comprimento - corpo: 10,0-10,4 mm; asa: 9,8-10,4 mm.

Semelhante ao macho, diferindo no que segue.

Espermateca (Fig. 21). Alongada, lateralmente com uma projeção na metade basal e uma invaginação na metade apical, sem membrana ao redor da base; dutos espermáticos finos, três vezes mais longos que as espermatecas.

Material examinado. BolíviA, Copinota: II.1948, 1 fêmea, H. Merubia leg. (NMNH); III.1948, 1 macho, H. Merubia leg. (NMNH). ARGENTINA ?: Campo Santa de Salta, 13.V.1927, 1 fêmea (NMNH) 
Registro geográfico. Bolívia (Copinota), Argentina ? (Salta).

Comentários. Fêmea descrita pela primeira vez.

\section{Euprepina maracajula Hull, 1971}

Fig. 8

Euprepina maracajula Hull, 1971; Painter et al., 1978.

Material tipo. Holótipo macho (NMNH): Maracajú/Mato Grosso/Brasil; Maio/1937; Serviço Febre/Amarela/M.E.S., Bras.; R C Shannon/Collection; Holotype/Euprepina/maracajula/Hull [manuscrito] [etiqueta vermelha]; em bom estado de preservação faltando: perna II esquerda; asa esquerda colada; halter esquerdo colado junto a asa; asa direita sem o ápice.

Diagnose. Probóscida curta, ultrapassando a margem oral em 3/4 do seu comprimento; transversa $\mathrm{r}-\mathrm{m}$ posicionada no $1 / 3$ distal da célula discal; abdômen com ápice de largura semelhante a base, nos machos, negro com tergito $\mathrm{V}$ branco.

Macho (Fig. 8). Comprimento - corpo: 10,5 mm; asa: 9,1 mm.

Cabeça. Fronte castanho escura; face castanho escura com polinosidade prateada na parte inferior; palpo de tamanho equivalente a $1 / 4$ do comprimento da probóscida, castanho escuro com base castanho clara, com cerdas amarelas na metade basal e castanho escuras na apical; probóscida ultrapassando a margem oral em 3/4 do seu comprimento; labelo curto; antenas com escapo castanho escuro com polinosidade cinza, um pouco maior que o pedicelo, com cerdas negras ao redor, mais longas lateralmente e abaixo; pedicelo castanho amarelado com cerdas negras do mesmo tamanho ao redor; triângulo ocelar com muitas cerdas de tamanho semelhante; occipício castanho com polinosidade cinza, com pêlos amarelos.

Tórax: dorso negro revestido com pêlos amarelo-pálidos; metanepisterno com longos pêlos amarelo-pálidos na metade posterior, catepisterno com longos pêlos amarelo-pálidos na metade anterior, anepisterno inteiramente recoberto por longos pêlos amarelo-pálidos; notopleura com três cerdas; calo pós-alar com longos pêlos branco amarelados; halter com haste amarela e capítulo amarelo; caliptra com pêlos brancos na margem. Pernas: fêmures castanhos e tíbias castanho amareladas; fêmures com escamas brancas, tíbias I e II com escamas brancas e III com escamas pretas. Perna I: coxa com longos pêlos brancos; fêmur com cerdas brancas longas e finas na face ventral, mais concentradas nos $2 / 3$ basais; tíbia com cerdas curtas espaçadas nas faces ântero-ventral, ântero-dorsal, póstero-ventral e póstero-dorsal; faces ântero-dorsal, póstero-dorsal, póstero-ventral e ventral com uma cerda apical, a última mais longa; tarso com cerdas curtas na face ventral; pré-tarso longo de tamanho equivalente a soma dos demais segmentos tarsais; unhas castanho claras com ápice negro e pulvilo de comprimento aproximadamente igual a unha. Perna II: coxa com longos pêlos brancos; fêmur com cerdas brancas longas e finas na face ventral mais concentradas nos $2 / 3$ basais; tíbia com cerdas curtas espaçadas nas faces ântero-ventral, ântero-dorsal, póstero-ventral e póstero-dorsal; 3 cerdas no 1/3 médio da face posterior; faces ântero-dorsal, póstero-dorsal, póstero-ventral e ventral com uma cerda apical, a última mais longa; tarso com cerdas curtas na face ventral; pré-tarso, unhas e pulvilos como na perna anterior. Perna III: coxa com 
longos pêlos brancos; fêmur na face ventral com cerdas brancas longas e finas, aproximadamente na metade basal e negras na apical; tíbia com cerdas curtas espaçadas nas faces ântero-ventral, ântero-dorsal, póstero-ventral e póstero-dorsal, mais desenvolvidas na primeira; faces ântero-dorsal, póstero-dorsal, póstero-ventral e ventral com uma cerda apical, a última mais longa; tarso com cerdas curtas na face ventral; pré-tarso longo medindo um pouco menos que a soma dos demais segmentos tarsais; unhas e pulvilos como na perna anterior. Asa: hialina com margem costal levemente tingida de castanho. Célula $\mathrm{r} 5$ largamente aberta na margem da asa, em uma distância maior que o tamanho da transversa r-m; célula anal aberta na margem da asa em uma distância menor, aproximadamente a metade, que o tamanho da transversa $\mathrm{r}-\mathrm{m}$; transversa $\mathrm{r}-\mathrm{m}$ posicionada no $1 / 3$ distal da célula discal deixando a célula br com o dobro do tamanho da célula bm.

Abdômen. Com ápice de largura semelhante à base, negro revestido com longos pêlos amarelos mais abundantes lateralmente até o segmento $\mathrm{V}$, do segmento VI até o ápice revestido por longos pêlos castanho avermelhados, tergito $\mathrm{V}$ branco.

Registro geográfico. Brasil (Mato Grosso).

Comentários. Fêmea desconhecida. Não foi autorizada a dissecção da terminália do exemplar.

\section{Euprepina truxalia Hull, 1971}

Figs $9,10,22,23,24$

Euprepina truxalia Hull, 1971; Painter et al., 1978; Lamas \& Couri, 1998.

Material tipo. Parátipo macho (C.N.C.): 24 kil. E. Formoso,/[Goiás] Go., Brazil/May 28, 1956/F. S. Truxal; MACHRIS BRAZILIAN/EXPEDITION - 1956/LOS ANGELES/COUNTY MUSEUM; PARATYPE/Euprepina/truxalia/Hull [manuscrito] [etiqueta amarela]; Frank M. Hull/Collection/C.N.C. 1981; no paratype/listed in/original/descrip. [manuscrito] [etiqueta amarela]; em bom estado de preservação, faltando: perna I esquerda e perna II direita; cobertura orogenal com lado esquerdo destruído.

Parátipo fêmea (C.N.C.). 24 kil. E. Formoso,/[Goiás] Go., Brazil/May 15, 1956/F. S. Truxal; MACHRIS BRAZILIAN/EXPEDITION -1956/LOS ANGELES/COUNTY MUSEUM; PARATYPE/Euprepina/truxalia/Hull [manuscrito] [etiqueta amarela]; Frank M. Hull/Collection/C.N.C. 1981; em bom estado de preservação, faltando: perna II esquerda e tarsos da perna III esquerda.

Diagnose. Labelo longo; abdômen com ápice muito mais estreito que a base, nos machos castanho com tergito $\mathrm{V}$ branco, tergito II castanho inteiramente recoberto de pêlos brancos, nas fêmeas castanho inteiramente recoberto com pêlos amarelos; distifalo curto, terminando junto com o ápice dos lobos do gonocoxito; apódema do edeago lateral curto, com ápice terminando antes da margem externa da gonocoxa em vista dorsal; espermateca ovalada, com uma projeção lateral mediana e membrana ao redor da base.

Macho (Fig. 9). Comprimento - corpo: 10,5-12,6 mm; asa: 9,4-12,3 mm.

Cabeça. Fronte castanho escura; face castanho escura com polinosidade 


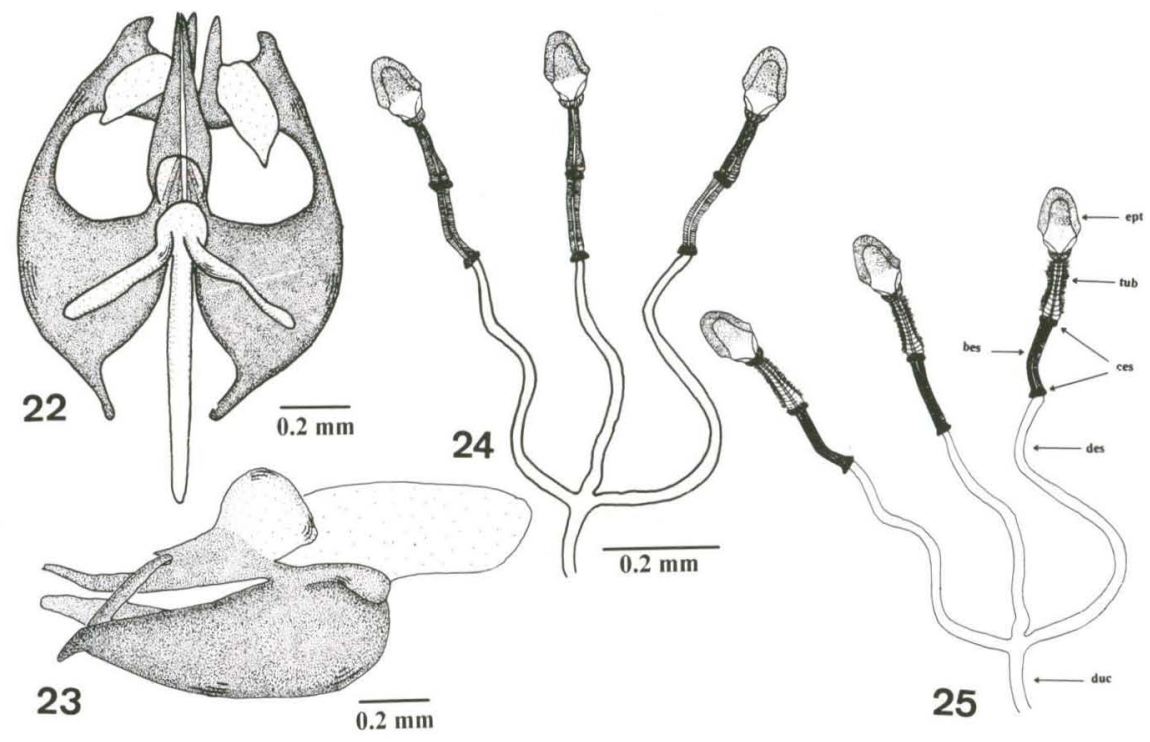

Figs 22-25. (22-24) Euprepina truxalia: (22) terminália masculina, vista dorsal; (23) terminália masculina, vista lateral; (24) espermateca; (25) modelo e nomenclatura da espermateca de Bombyliidae.

prateada na parte inferior; palpo de tamanho equivalente a $1 / 5$ do tamanho da probóscida (sem o labelo), castanho escuro, com base castanho clara e cerdas castanho escuras ao redor; probóscida ultrapassando a margem oral em $4 / 5$ do seu comprimento; labelo longo; antenas com escapo castanho escuro com polinosidade cinza, um pouco maior que o pedicelo com cerdas castanhas e curtas acima e cerdas mais longas castanho amareladas abaixo; pedicelo castanho com polinosidade cinza e extremo ápice amarelo com cerdas negras do mesmo tamanho ao redor; triângulo ocelar com muitas cerdas de tamanhos variados; occipício com polinosidade prateada, longos pêlos amarelo avermelhados e pequenos pêlos negros.

Tórax. Dorso castanho revestido com pêlos amarelos no $1 / 3$ anterior do escudo, o restante incluindo o escutelo com pêlos amarelo avermelhados; metanepisterno com longos pêlos amarelo-pálidos na metade posterior; catepisterno com delicados pêlos amarelo avermelhados na metade anterior; anepisterno inteiramente recoberto por longos pêlos amarelo avermelhados; notopleura com cinco cerdas; calo pós-alar com pêlos castanhos e amarelo avermelhados; calíptras com pêlos amarelos (ou castanho avermelhados) na margem. Pernas: fêmures e tíbias castanho escuros com escamas amarelo avermelhadas, polinosas sob certa iluminação. Perna I: coxa com longos pêlos castanho avermelhados na face anterior; fêmur com pêlos castanho avermelhados na face ventral; tíbia com fileiras de cerdas curtas espaçadas nas faces ântero-ventral, ântero-dorsal, póstero-ventral e póstero-dorsal; faces ântero-dorsal, póstero-dorsal, póstero-ventral e ventral com uma cerda apical, a última mais longa; tarso com cerdas curtas na face ventral; pré-tarso longo, de tamanho equivalente a soma dos demais segmentos tarsais; unhas castanho claras com ápice 
negro e pulvilo de comprimento aproximadamente igual a unha. Perna II: coxa com longos pêlos castanho avermelhados na face anterior; fêmur com fileira de cerdas castanho avermelhadas na face ventral; tíbia com fileira de cerdas curtas espaçadas nas faces ântero-ventral, ântero-dorsal, póstero-ventral e póstero-dorsal; faces ântero-dorsal, póstero-dorsal, póstero-ventral e ventral com uma cerda apical, a última mais longa; tarsos, unhas e pulvilos como na perna anterior. Perna III: coxa com longos pêlos brancos na face anterior; fêmur com fileira de cerdas castanho avermelhadas na face ventral nos $2 / 3$ basais. tíbia com fileira de cerdas curtas espaçadas nas faces ântero-ventral, ântero-dorsal, póstero-ventral e póstero-dorsal, mais desenvolvidas na primeira; faces ântero-dorsal, póstero-dorsal, póstero-ventral e ventral com uma cerda apical, a última mais longa; tarso com cerdas curtas na face ventral; pré-tarso longo, medindo um pouco menos que a soma dos demais segmentos tarsais; unhas e pulvilos como na perna anterior. Asa: hialina levemente castanha na base e margem anterior; célula $\mathrm{r} 5$ aberta na margem da asa em uma distância aproximadamente igual ao tamanho da transversa $\mathrm{r}-\mathrm{m}$; célula anal estreitamente aberta na margem da asa, em uma distância equivalente a $1 / 2$ do tamanho da transversa $\mathrm{r}-\mathrm{m}$; transversa $\mathrm{r}-\mathrm{m}$ posicionada no $1 / 3$ distal da célula discal, deixando a célula br $1 / 3$ maior que a célula bm.

Abdômen. Com ápice muito mais estreito que a base, castanho com tergito $\mathrm{V}$ branco, tergitos II e $\mathrm{V}$ inteiramente recobertos por longos pêlos brancos, demais tergitos com pêlos castanho avermelhados; segmentos III e IV lateralmente com pêlos castanho avermelhados superiormente e brancos inferiormente; com pêlos brancos ventralmente.

Terminália (Figs 22, 23). Gonocoxa alta em vista lateral com extremo ápice afilado e voltado para baixo; distifalo curto, terminando junto com o ápice dos lobos do gonocoxito; apódema do edeago lateral curto, com ápice terminando antes da margem externa da gonocoxa em vista dorsal; apódema ejaculatório com margem regular em vista lateral.

Fêmea (Fig. 10). Comprimento - corpo: 10,0-10,4 mm; asa: 12,4-13,2 mm.

Semelhante ao macho, diferindo no que segue.

Cabeça. Face castanha com polinosidade cinza; palpo castanho escuro com base castanho clara e cerdas amarelas na metade basal e castanho avermelhadas na apical; antenas com escapo castanho com polinosidade cinza, um pouco maior que o segundo com cerdas amarelas ao redor, mais longas lateralmente e abaixo; triângulo ocelar com longas cerdas amarelas; occipício com polinosidade prateada e longos pêlos amarelo avermelhados.

Tórax. Dorso castanho revestido com pêlos amarelos; catepisterno com pêlos amarelos na metade anterior; anepisterno inteiramente recoberto por longos pêlos amarelos; calo pós-alar com pêlos amarelos. Pernas: fêmures e tíbias castanho escuros com escamas amarelas. Perna I: coxa com longos pêlos amarelos na face anterior; fêmur recoberto por pêlos amarelos na face ventral. Perna II: coxa com longos pêlos amarelos; fêmur com fileira de cerdas amarelas na face ventral. Perna III: coxa com longos pêlos amarelos.

Abdômen. Castanho inteiramente recoberto por pêlos amarelos; do segmento VI ao ápice com esparsas cerdas castanhas misturadas aos pêlos amarelos. 
Espermateca (Fig. 24). Ovalada, com projeção lateral mediana e membrana ao redor da base; dutos espermáticos finos, cinco vezes mais longos que as espermatecas.

Material examinado. BRASIL, Pernambuco: Alto da Serra Negra, V.1960, 1 macho, A. Machado leg. (MZUSP); Petrolina (10 km ao norte), VII.1974, 1 macho, N. Papavero leg. (MZUSP); Bahia, Vila Nova, 18.IV.1976, 1 macho (MZUSP); Goiás: Pirenópolis, 22.V.1938, 1 fềmea, F. Lane leg. (MZUSP); São Paulo: Batatais, III.1943, 4 machos, A. Stafuzza leg. (MZUSP).

Registro geográfico. Brasil (Pernambuco, Bahia, Goiás e São Paulo).

Comentários. Fêmea descrita pela primeira vez.

AGRADECIMENTOS. À Dra. Denise Pamplona (Museu Nacional, UFRJ) pela revisão crítica deste manuscrito. Ao Dr. Sergio Fragoso (EMBRAPA/UFRJ) pelas fotografias. Aos curadores das diversas instituições que nos emprestaram material tipo e outros espécimens.

\section{REFERÊNCIAS BIBLIOGRÁFICAS}

ARTIGAS, J.N. 1971. Las estructuras quitinizadas de la spermatheca y funda del pene de los asilidios y su valor sistematico a traves del studio por taxonomia numerica (Diptera, Asilidae). Gayana. Zool. 18: 1-106.

EvenHUIS, N.L. 1983. An indexed bibliography of Bombyliidae (Insecta, Diptera). Theses Zoologicae Vol. 4. Braunschweig: J. Cramer.

- 1991. World catalog of the genus-group names of bee flies (Diptera: Bombyliidae). Bishop Mus. Bull. Entomol. 5: 1-105.

HULL, F.M. 1971. A new genus and species of beeflies (Diptera, Bombyliidae).

Proc. Ent. Soc. Wash. 73 (2): 181-183.

1973. The beeflies of the world. The genera of the family Bombyliidae.

Bull. U.S. Nat. Mus. 286: 3-687.

LAMAS, C.J.E. \& M.S. Couri. 1998. A new species of Euprepina Hull, 1971 from Bahia, Brazil (Diptera: Bombyliidae: Bombyliinae). Revta bras. Ent. 41 (2-4): 447-449.

MCALPINE, J.F. 1981. Morphology and terminology - Adults, p.9-63. In: J.F. MCAlPINE; B.V. Peterson; G.E. SHEwell; H.J. TeSKey; J.R. VOCKeroth \& D.M. WooD (Eds). Manual of Neartic Diptera. Ottawa, Research Branch, Agriculture Canada, Monograph 27, Vol. 1, VI+674p.

NAGATOMI, A. \& N. LiU. 1995. Spermatheca and female terminalia of Pantophthalmidae and Xylophagidae s. lat. (Diptera). Ann. Entomol. Soc. Amer. 88 (5): 603-626.

PAINTER, R.H. \& E.M. PAINTER. 1974. Notes on and redescriptions of types of South American Bombyliidae (Diptera) in European and United States Museums. Res. publ. Kansas State Univ. Expt. Sta. 168: 1-322.

PAinTER, R.H.; E.M. PAINTER \& J.C. Hall. 1978. Family Bombyliidae. In: A Catalogue of the Diptera of the Americas South of the United States 38, p.1-92.

WIEDEMANN, C.R.W. 1830. Aussereuropäische zweiflügelige Insekten. Hamm, 
Parte II, XII+684+XIp.

YEATES, D.K. 1988. Revision of the Australian genus Oncodosia Edwards (Diptera, Bombyliidae). Syst. Entomol. 13: 503-520. 1994. The cladistic and classification of the Bombyliidae (Diptera: Asiloidea). Bull. Amer. Mus. Nat. Hist. 219: 1-191.

Recebido em 29.VIII.1997; aceito em 07.IV.1999. 